\title{
Endothelium-dependent responses in human isolated thyroid arteries from donors
}

\author{
Belén Torondel ${ }^{1}$, José M Vila ${ }^{1}$, Gloria Segarra ${ }^{2}$, Paloma Lluch ${ }^{3}$, \\ Pascual Medina ${ }^{1}$, Juan Martínez-León ${ }^{4}$, Joaquin Ortega ${ }^{4}$ and \\ Salvador Lluch ${ }^{1}$ \\ ${ }^{1}$ Department of Physiology, University of Valencia, 46010 Valencia, Spain \\ ${ }^{2}$ Research Unit, Hospital Clínico, 46010 Valencia, Spain \\ ${ }^{3}$ Department of Medicine, University of Valencia, 46010 Valencia, Spain \\ ${ }^{4}$ Department of Surgery, University of Valencia, 46010 Valencia, Spain \\ (Requests for offprints should be addressed to S Lluch; Email: lluchs@post.uv.es)
}

\begin{abstract}
The functional properties of the endothelium of human thyroid arteries remain unexplored. We investigated the intervention of nitric oxide (NO), prostacyclin $\left(\mathrm{PGI}_{2}\right)$ and endothelium-derived hyperpolarizing factor (EDHF) in the responses to acetylcholine and noradrenaline in isolated thyroid arteries obtained from multi-organ donors. Artery rings were suspended in organ baths for isometric recording of tension. The contribution of $\mathrm{NO}, \mathrm{PGI}_{2}$ and $\mathrm{EDHF}$ to endothelium-dependent relaxation was determined by the inhibitory effects of $N^{G}$-monomethyl-L-arginine (L-NMMA), indomethacin, and $\mathrm{K}^{+}$channel inhibitors respectively. Acetylcholine induced concentrationdependent relaxation; this effect was not modified by indomethacin and was only partly reduced by L-NMMA, but was abolished in endothelium-denuded rings. The
\end{abstract}

relaxation resistant to indomethacin and L-NMMA was abolished by using either apamin combined with charybdotoxin, ouabain plus barium, or a high- $\mathrm{K}^{+}$solution. Noradrenaline induced concentration-dependent contractions which were of greater magnitude in arteries denuded of endothelium or in the presence of L-NMMA.

In conclusion, the results indicate that in human thyroid arteries the endothelium significantly modulates responses to acetylcholine and noradrenaline through the release of NO and EDHF. EDHF plays a dominant role in acetylcholine-induced relaxation through activation of $\mathrm{Ca}^{2+}$-activated $\mathrm{K}^{+}$channels, inwardly rectifying $\mathrm{K}^{+}$ channels and $\mathrm{Na}^{+}-\mathrm{K}^{+}$-ATPase.

Journal of Endocrinology (2004) 181, 379-384

\section{Introduction}

The functional properties of the endothelium-nitric oxide (NO) system of human thyroid arteries remain largely unexplored. Nitric oxide synthase, the enzyme responsible for the formation of NO (Palmer et al. 1988) is present in the thyroid follicular cells and in endothelial cells of the human thyroid gland (Colin et al. 1997), and human thyrocites produce the endogenous NO synthase inhibitor asymmetric-dimethyl-L-arginine (ADMA; Millatt et al. 2000). NO production, measured as plasma nitrite-plusnitrate concentrations, is decreased in hyperthyroid patients when compared with controls (Hermenegildo et al. 2002). Hyperthyroid patients also revealed a significant increase in plasma levels of ADMA. Because ADMA increases the tone of peripheral vessels by inhibiting the basal release of NO from the endothelium (Vallance et al. 1989), it is conceivable that an increase in ADMA in hyperthyroidism might represent a compensatory mech- anism to decrease NO production and, consequently, to counterbalance excessive peripheral vasodilatation (Hermenegildo et al. 2002). All these results are consistent with a role for $\mathrm{NO}$ in the vascular changes observed in thyroid dysfunction.

Receptor-dependent agonists, such as acetylcholine, induce endothelium-dependent smooth muscle relaxation by activating $\mathrm{NO}$ synthase and cyclooxygenase to produce $\mathrm{NO}$ and prostacyclin $\left(\mathrm{PGI}_{2}\right)$ respectively (Lüscher \& Vanhoutte 1990, Suzuki \& Cheng 1990, Cohen \& Vanhoutte 1995, Shimokawa \& Takeshita 1995, Vanhoutte 1996). In addition, after inhibition of NO synthase and cyclooxygenase, stimulation of the endothelium evokes smooth muscle relaxation that has been attributed to a factor called endothelium-derived hyperpolarizing factor $(E D H F)$. Although the nature of EDHF is not known, experimental evidence suggests that the action of EDHF involves activation of endothelial $\mathrm{K}^{+}$channels that are inhibited by the combination of apamin and 
charybdotoxin (Petersson et al. 1997, Zygmunt et al. 1997, Edwards et al. 1998, Doughty et al. 1999). This implicates a role for small- and intermediate-conductance $\mathrm{Ca}^{2+}$ activated $\mathrm{K}^{+}$channels (Zygmunt 1996) in endotheliumdependent relaxation. In addition, the release of EDHF leads to activation of smooth muscle inwardly rectifying $\mathrm{K}^{+}$channels and $\mathrm{Na}^{+}-\mathrm{K}^{+}$ATP-ase pumps (Edwards et al. 1998). The aim of the present study was to detect the respective intervention of endothelium-derived $\mathrm{NO}$, $\mathrm{PGI}_{2}$ and EDHF in the responses to acetylcholine and noradrenaline in human isolated thyroid arteries obtained from multi-organ donors.

\section{Materials and Methods}

Glandular branches of the superior thyroid artery were obtained from 14 multi-organ donors during procurement of organs for transplantation (ten men and four women; age range: $22-55$ years; cause of death: nine head trauma, three intracranial hemorrhage, two myocardial infarction). The study was approved by the ethical committee of our institution. The vessels were immediately placed in a petri dish containing refrigerated $\left(4^{\circ} \mathrm{C}\right)$ modified Krebs-Henseleit solution of the following composition (in $\mathrm{mmol} / \mathrm{l}$ ): $\mathrm{NaCl}, 115 ; \mathrm{KCl}, 4 \cdot 6 ; \mathrm{MgCl}_{2} \cdot 6 \mathrm{H}_{2} \mathrm{O}, 1 \cdot 2$; $\mathrm{CaCl}_{2}, 2 \cdot 5 ; \mathrm{NaHCO}_{3}, 25$; glucose, 11.1; disodium EDTA, $0 \cdot 01$.

Experiments started within $8 \mathrm{~h}$ after organs were removed. Arteries were cleaned of connective tissue and cut into rings ( $3 \mathrm{~mm}$ in length) under a dissecting microscope. In some experiments, the endothelium was removed mechanically by inserting a roughened stainlesssteel wire into the lumen and gently rolling the vessel ring on wet filter paper. Each ring was suspended between two stainless-steel L-shaped pins in 4-ml organ baths containing modified Krebs solution. The solution was equilibrated with $95 \%$ oxygen and $5 \%$ carbon dioxide to give a $\mathrm{pH}$ of $7 \cdot 3-7 \cdot 4$ and was maintained at $37^{\circ} \mathrm{C}$ with a circulating water jacket and a heat pump. One pin was fixed to the organ-bath wall and the other was connected to a strain gauge (model FT03; Grass Instrument Division of Astro-Med Inc, West Warwick, RI, USA). Changes in isometric force were recorded on a Macintosh computer (Apple Computer, Cupertino, CA, USA) by use of Chart version 3.4/s software and a MacLab/8e data acquisition system (ADInstruments, Mountain View, CA, USA). To establish the resting tension for maximal force development, we performed a series of preliminary experiments on thyroid artery rings which were exposed repeatedly to $100 \mathrm{mmol} / 1 \mathrm{KCl}$. Basal tension was increased gradually until contractions were maximal. The optimal resting tension was $1 \mathrm{~g}$. The rings were allowed to attain a steady level of tension during a 2- to 3-h accomodation period before testing. Functional integrity of the endothelium was confirmed routinely by the presence of relaxation induced by acetylcholine $(0 \cdot 1-1 \mu \mathrm{mol} / \mathrm{l})$ during contraction obtained with noradrenaline $(1-3 \mu \mathrm{mol} / \mathrm{l})$. Arteries in which the acetylcholine reversed the noradrenaline-induced tone by more than $70 \%$ were designated as endothelium intact and arteries in which acetylcholine caused less than 15\% relaxation were designated as denuded (Martínez et al. 1994, Medina et al. 1997).

Relaxations to acetylcholine $(1 \mathrm{nmol} / 1$ to $1 \mu \mathrm{mol} / \mathrm{l})$ were investigated in arteries precontracted with noradrenaline to $40-60 \%$ of the contraction induced by $100 \mathrm{mmol} / 1 \mathrm{KCl}$ under the following conditions: (1) in the absence of inhibitors (control response); (2) in the presence of indomethacin $(10 \mu \mathrm{mol} / \mathrm{l})$ to inhibit the production of $\mathrm{PGI}_{2} ;$ (3) in the presence of indomethacin and $N^{\mathrm{G}}$-monomethyl-L-arginine (L-NMMA, $100 \mu \mathrm{mol} / \mathrm{l}$ ) to inhibit the production of $\mathrm{PGI}_{2}$ and $\mathrm{NO}$ synthase respectively; (4) in the presence of indomethacin, L-NMMA and $\mathrm{KCl}(20 \mathrm{mmol} / \mathrm{l})$ to inhibit the production of $\mathrm{PGI}_{2}$, NO synthase and $\mathrm{K}^{+}$channel activity respectively. To examine the nature of $\mathrm{K}^{+}$channel activation, concentrationresponse curves to acetylcholine were established in the presence of indomethacin plus L-NMMA combined with one of the following inhibitors: iberiotoxin $(0 \cdot 1 \mu \mathrm{mol} / \mathrm{l})$, an inhibitor of large-conductance $\mathrm{Ca}^{2+}$-activated $\mathrm{K}^{+}$ channels; charybdotoxin $(0 \cdot 1 \mu \mathrm{mol} / \mathrm{l})$, an inhibitor of both large- and intermediate-conductance $\mathrm{Ca}^{2+}$-activated $\mathrm{K}^{+}$channels; apamin $(1 \mu \mathrm{mol} / \mathrm{l})$, an inhibitor of smallconductance $\mathrm{Ca}^{2+}$-activated $\mathrm{K}^{+}$channels, and glibenclamide $(10 \mu \mathrm{mol} / \mathrm{l})$, a selective blocker of ATP-sensitive $\mathrm{K}^{+}$ channels. Control (in the absence of inhibitors) and experimental (after incubation for $20 \mathrm{~min}$ with inhibitors) responses were obtained from separate preparations. In another set of experiments, we determined the effects of barium alone $(3 \mu \mathrm{mol} / 1$, a blocker of inwardly rectifying $\mathrm{K}^{+}$channels $)$or combined with ouabain $(1 \mathrm{mmol} / \mathrm{l}$, an inhibitor of $\mathrm{Na}^{+}-\mathrm{K}^{+}$-ATPase).

Concentration-response curves for noradrenaline were determined in the absence and in the presence of L-NMMA $(100 \mu \mathrm{mol} / \mathrm{l})$ in separate vascular preparations with or without endothelium.

\section{Chemicals}

All substances were purchased from Sigma.

\section{Data analysis}

All values are expressed as means \pm S.E.M. Contractile effects were expressed as a percentage of the response to $\mathrm{KCl}(100 \mathrm{mmol} / \mathrm{l})$. Relaxation was expressed as a percentage of inhibition of noradrenaline-induced contraction. The concentrations of agonist producing half-maximum effect $\left(\mathrm{EC}_{50}\right.$ values) were expressed as $\mathrm{pD}_{2}\left(-\log \mathrm{EC}_{50}\right)$. The $\mathrm{pD}_{2}$ values were compared by an unpaired $t$-test 


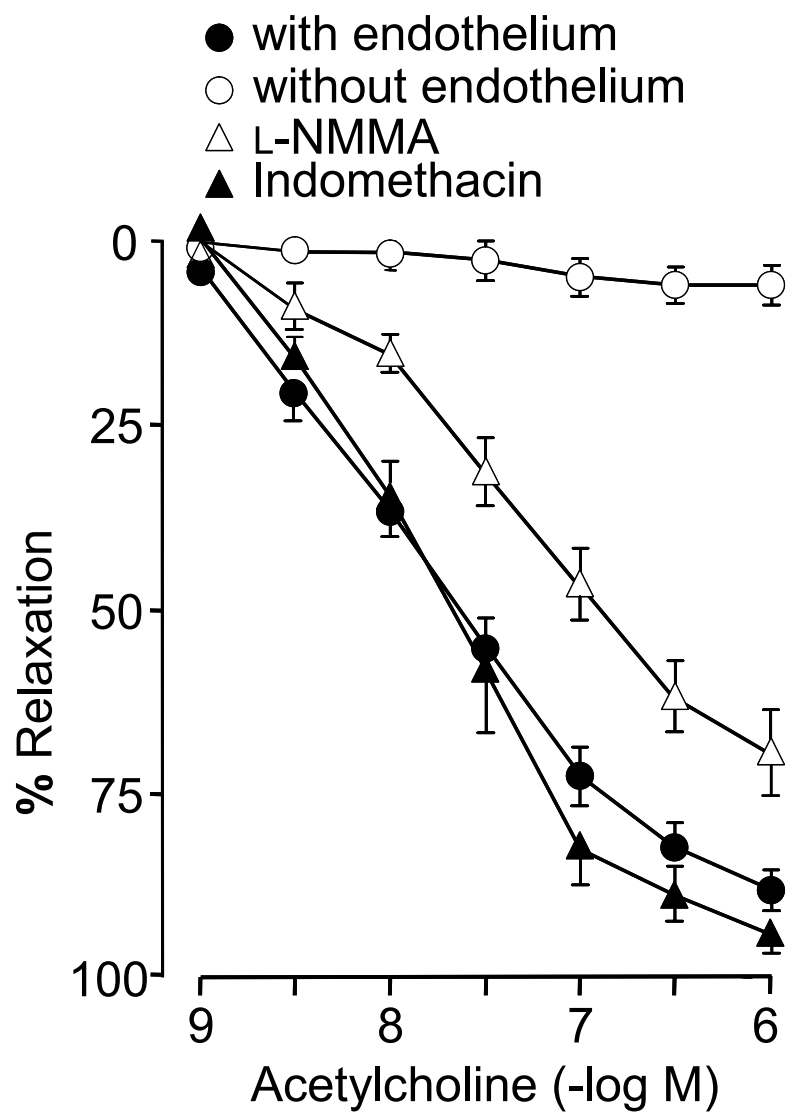

Figure 1 Concentration-response curves to acetylcholine in artery rings with $(n=7)$ and without $(n=7)$ endothelium and in the presence of L-NMMA $(100 \mu \mathrm{mol} / \mathrm{l}, n=6)$ or indomethacin $(10 \mu \mathrm{mol} / \mathrm{l}, n=4)$. Values are means \pm S.E.M.

and two-way ANOVA. $n$ values are presented as the number of donors. Statistical significance was accepted at $P<0.05$.

\section{Results}

Acetylcholine caused concentration-dependent relaxations in arteries with an intact endothelium (Fig. 1). This relaxant effect was not modified by indomethacin and only partly reduced by L-NMMA $(P<0 \cdot 05)$, but was abolished in endothelium-denuded rings (Fig. 1, Table 1).

The remaining endothelium-dependent maximal relaxation (Emax), resistant to indomethacin and NO synthase inhibition, was further reduced by pretreatment with $20 \mathrm{mmol} / 1 \mathrm{KCl}$ or the combination of charybdotoxin and apamin (Fig. 2; before treatment: $\mathrm{pD}_{2} 7 \cdot 33 \pm 0 \cdot 20$, $E_{\max } 72 \pm 5 \%$; after KCl: $\mathrm{pD}_{2} 7 \cdot 30 \pm 0 \cdot 13, P>0 \cdot 05, E_{\max }$ $23 \pm 3 \%, \quad P<0.05$; after charybdotoxin plus apamin: $\left.\mathrm{pD}_{2} \quad 7 \cdot 45 \pm 0 \cdot 20, \quad P>0 \cdot 05, \quad E_{\max } 27 \pm 4 \%, \quad P<0 \cdot 05\right)$. Incubation with charybdotoxin or apamin alone, or the
Table $1 \mathrm{pD}_{2}$ and maximal responses values for acetylcholine and noradrenaline

\begin{tabular}{|c|c|c|}
\hline & $\mathrm{pD}_{2}$ & $\operatorname{Emax}(\%)$ \\
\hline \multicolumn{3}{|l|}{ Treatment } \\
\hline \multicolumn{3}{|l|}{ Acetylcholine } \\
\hline Control & $7 \cdot 76 \pm 0 \cdot 20$ & $88 \pm 3(7)$ \\
\hline L-NMMA & $7 \cdot 33 \pm 0 \cdot 11^{*}$ & $72 \pm 5^{*}(6)$ \\
\hline \multicolumn{3}{|c|}{ Noradrenaline } \\
\hline Control & $5 \cdot 98 \pm 0 \cdot 29$ & $102 \pm 11$ \\
\hline L-NMMA & $6 \cdot 52 \pm 0.31^{*}$ & $120 \pm 6^{*}(6)$ \\
\hline
\end{tabular}

Values are means \pm S.E.M.

${ }^{*} \mathrm{P}<0 \cdot 05$ versus control.

Number of donors in parenthesis.

combination of apamin and iberiotoxin, did not change the acetylcholine-induced relaxation significantly $(P>0 \cdot 05$; Fig. 2). Glibencamide, a blocker of ATP-sensitive $\mathrm{K}^{+}$ channels, had no significant effect on acetylcholineinduced relaxation (data not shown).

The relaxation to acetylcholine in arteries exposed to L-NMMA plus indomethacin was slightly decreased in the presence of barium (Fig. 3; before barium: $\mathrm{pD}_{2}$ $7 \cdot 33 \pm 0 \cdot 20, E_{\max } 72 \pm 5 \%$; after barium, $\mathrm{pD}_{2} 7 \cdot 15 \pm$ $\left.0 \cdot 30, P>0 \cdot 05, E_{\max } 43 \pm 6 \%, P<0 \cdot 05\right)$. In the presence

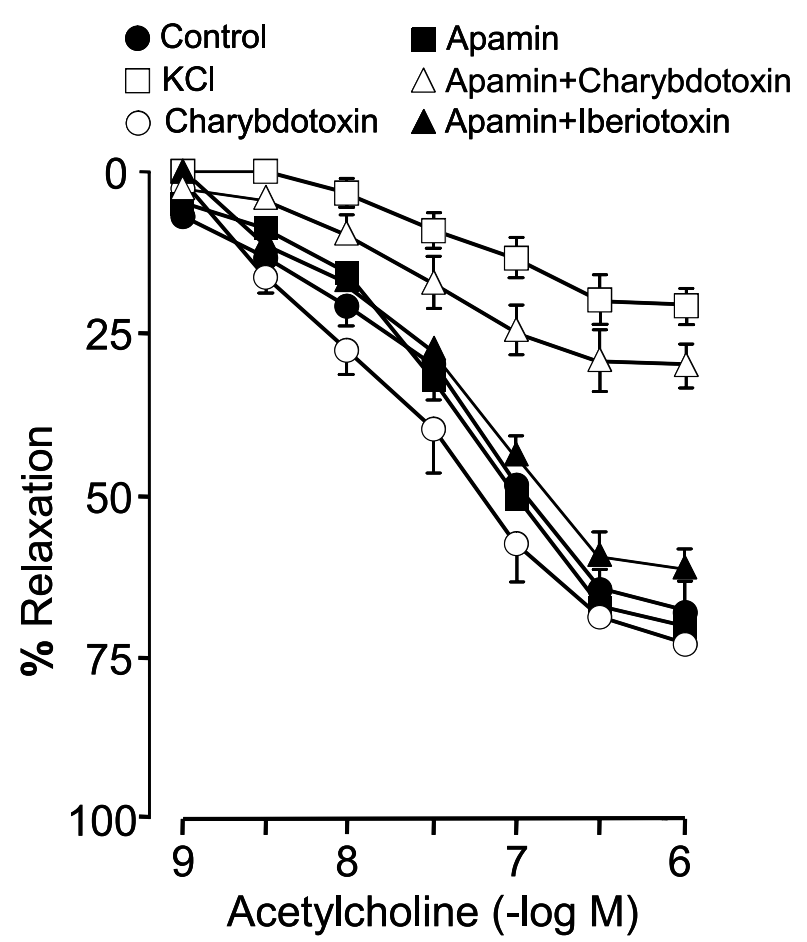

Figure 2 Concentration-response curves to acetylcholine in the absence (control, $n=6)$ and in the presence of $\mathrm{KCl}(20 \mathrm{mmol} / \mathrm{l}$, $n=5)$, charybdotoxin $(0 \cdot 1 \mu \mathrm{mol} / \mathrm{l}, n=6)$, apamin $(1 \mu \mathrm{mol} / \mathrm{l}, n=6)$, apamin plus charybdotoxin $(n=6)$ and apamin plus iberiotoxin $(0 \cdot 1 \mu \mathrm{mol} / \mathrm{l}, n=6)$. L-NMMA and indomethacin were present throughout. Values are means \pm S.E.M. 
$\triangle$ Control

- Barium

- Barium+Ouabain

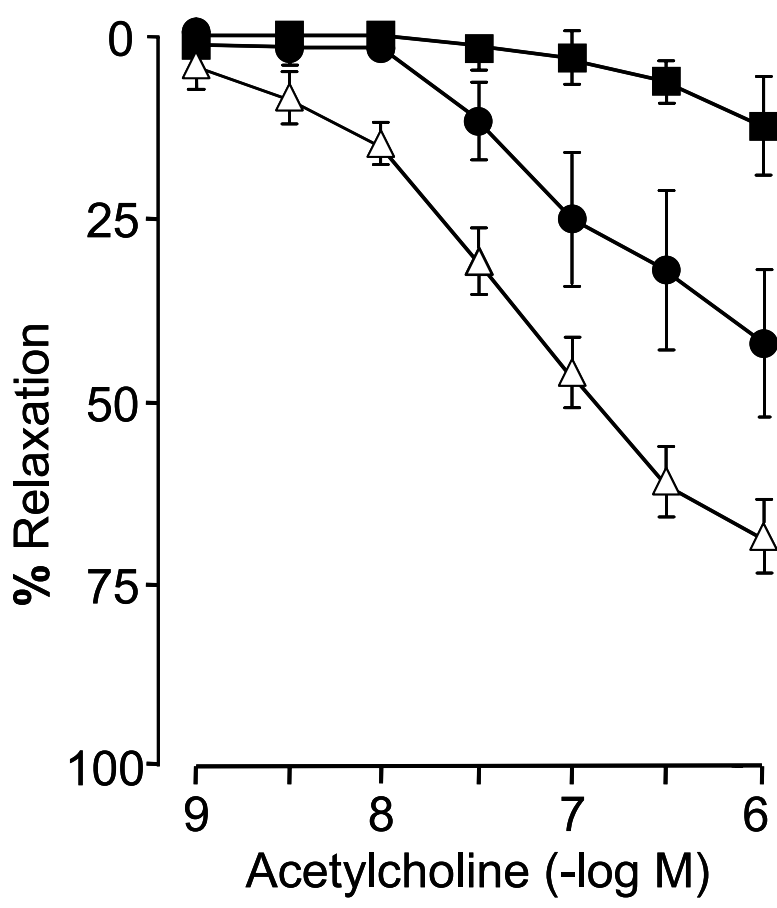

Figure 3 Relaxation to acetylcholine in the absence (control, $n=7$ ) and in the presence of barium $(3 \mu \mathrm{mol} / \mathrm{l}, n=5)$ and barium plus ouabain $(1 \mathrm{mmol} / \mathrm{l}, n=5)$. Indomethacin and L-NMMA were present throughout. Values are means \pm S.E.M.

of barium plus ouabain the relaxation to acetylcholine was further reduced ( $\left.E_{\max } 12 \pm 6 \%, P<0 \cdot 05\right)$.

There was no significant difference in the contractile response to $100 \mathrm{mM} \mathrm{KCl}$ between intact and endothelium-denuded artery rings $(2162 \pm 270$ vs $2475 \pm 225 \mathrm{mg}, n=6$ for each group, $P>0 \cdot 05)$. Noradrenaline produced concentration-dependent contractions which were of greater magnitude in arteries without endothelium (Fig. 4, Table 1). Treatment with the NO synthase inhibitor L-NMMA induced a parallel leftward shift (about 3 times) $(P<0 \cdot 05)$ of the response to noradrenaline in arteries with endothelium and did not modify significantly $(P>0.05)$ the concentration-response curve to noradrenaline in arteries without endothelium (not shown). The potentiation induced by L-NMMA in arteries with endothelium was completely reversed by L-arginine (1 mmol/l, Fig. 4).

\section{Discussion}

The present study in human thyroid arteries demonstrates that the endothelium modulates the responses to acetyl-

\section{with endothelium - without endothelium - L-NMMA \\ $\Delta$ L-NMMA+L-arginine}

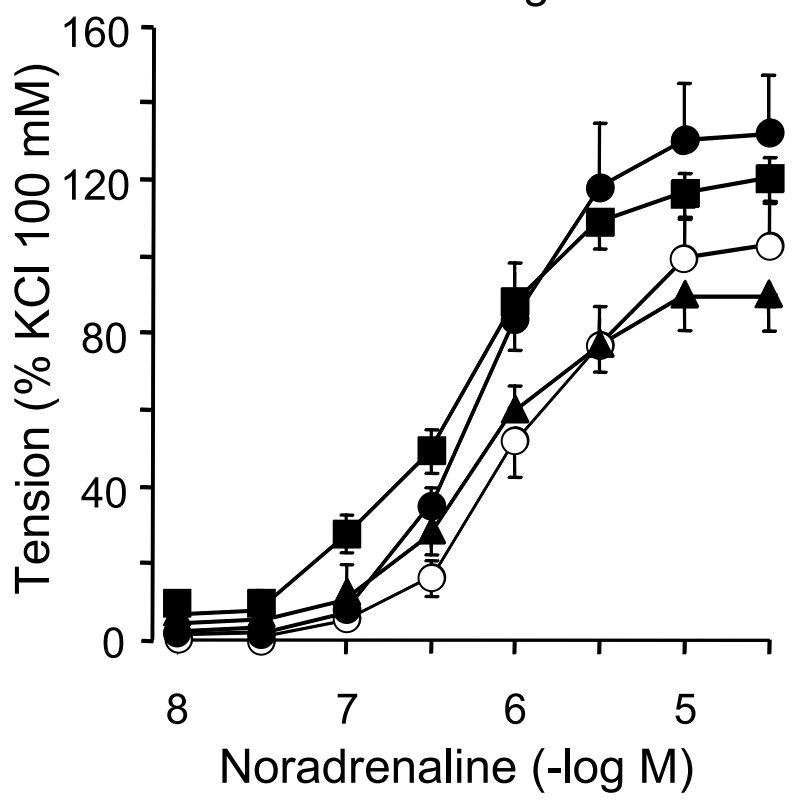

Figure 4 Concentration-response curves to noradrenaline in artery rings with $(n=7)$ and without $(n=6)$ endothelium and in the presence of L-NMMA $(100 \mu \mathrm{mol} / \mathrm{l}, n=6)$ and L-NMMA plus L-arginine $(1 \mathrm{mmol} / \mathrm{l}, n=5)$. Values are means \pm S.E.M.

choline and noradrenaline. The relaxation to acetylcholine appears to be endothelium dependent because mechanical removal of the endothelium inhibited the response. The findings of the present study indicate that the order of $\mathrm{pD}_{2}$ values for noradrenaline and acetylcholine in thyroid arteries corresponds to those determined in other human arteries (Martínez et al. 1994, Medina et al. 1997, Segarra et al. 2002).

Treatment with L-NMMA, an inhibitor of NO synthase (Rees et al. 1989, 1990) reduced the relaxation to acetylcholine in arteries with endothelium thus indicating the intervention of $\mathrm{NO}$ in this effect. However, the NO component, sensitive to L-NMMA, accounted for only $20 \%$ of the maximum relaxation to acetylcholine. Moreover, treatment with the cyclooxygenase inhibitor indomethacin did not change the endothelium-dependent relaxation, indicating that $\mathrm{PGI}_{2}$ does not modulate the relaxation response under these conditions. Therefore, the remaining relaxation, insensitive to L-NMMA and indomethacin, appears to be the major component of endothelium-dependent relaxation. This $\mathrm{NO} / \mathrm{PGI}_{2}-$ independent relaxation may result from the release by acetylcholine of EDHF (Feletou \& Vanhoutte 1988, Taylor \& Weston 1988). The large EDHF-induced 
relaxation in response to acetylcholine observed in the thyroid artery is comparable to that shown in the radial artery (Segarra et al. 2000) and in subcutaneous resistance arteries (Coats et al. 2001).

There is no clear agreement on the identity or the mechanisms by which EDHF relaxes vascular smooth muscle. In humans, the existence of EDHF has been demonstrated in vitro and in vivo (Urakami-Harasawa et al. 1997, Miura et al. 1999, Coats et al. 2001, Katz \& Krum 2001). Several candidates for EDHF have been proposed including endothelium-derived $\mathrm{K}^{+}$ions (Edwards et al. 1998), epoxyeicosatrienoic acid (Campbell et al. 1996, Fisslthaler et al. 1999) hydrogen peroxide (Matoba et al. 2000, 2002, Yada et al. 2003), anandamide (Randall et al. 1996) and C-type natriuretic peptide (Chauhan et al. 2003). Experimental evidence in small arteries suggests that receptor-dependent agonists, such as acetylcholine, may induce the release of EDHF by opening endothelial $\mathrm{K}^{+}$channels that are sensitive to charybdotoxin plus apamin but are unaffected by iberiotoxin alone or iberiotoxin combined with apamin (Edwards et al. 1998, Doughty et al. 1999, Coats et al. 2001, Scotland et al. 2001). These results in small arteries indicate that largeconductance, $\mathrm{Ca}^{2+}$-activated $\mathrm{K}^{+}$channels are not involved in the acetylcholine-induced release of EDHF. Our results in relatively large human thyroid arteries indicate that the EDHF component involves activation of $\mathrm{Ca}^{2+}$-dependent $\mathrm{K}^{+}$channels, sensitive to charybdotoxin and apamin, a finding similar to that observed in human subcutaneous arteries (Coats et al. 2001).

In certain vascular preparations, EDHF stimulates smooth muscle inwardly rectifying $\mathrm{K}^{+}$channels and $\mathrm{Na}^{+}-\mathrm{K}^{+}$-ATPase (Edwards et al. 1998). This induces hyperpolarization and relaxation. In our experiments, the combination of barium plus ouabain abolished the relaxation resistant to L-NMMA and indomethacin. These results indicate that EDHF released by acetylcholine is associated with activation of inwardly rectifying $\mathrm{K}^{+}$ channels and $\mathrm{Na}^{+}-\mathrm{K}^{+}$-ATPase.

We observe that treatment with L-NMMA, an inhibitor of NO synthase, augmented the contractile responses to noradrenaline. Inhibitors of NO synthase have been previously reported to increase noradrenaline-induced constriction in several experimental preparations (Angus et al. 1986, Jones et al. 1993, Martínez et al. 1994, Segarra et al. 1999). This effect is attributed to the inhibition by L-NMMA of the depressant influence of endothelial NO released by noradrenaline through stimulation of $\alpha_{2}$ adrenoceptors on endothelial cells (Angus et al. 1986) or through indirect mechanisms involving a signal conducted from smooth muscle to adjacent endothelial cells (Dora et al. 1997). It has been hypothesized that the rise in smooth muscle cell $\mathrm{Ca}^{2+}$ generates a diffusion gradient that drives $\mathrm{Ca}^{2+}$ through myoendothelial cell junctions and into the endothelial cells, thereby causing the synthesis of NO (Dora et al. 1997). It is also possible that the EDHF is also formed after noradrenaline-induced constriction. The study of this possibility has not been attempted in the present report. However, experiments in rat small mesenteric arteries have shown that the release of EDHF can be evoked indirectly by stimulation of $\alpha_{1}$ adrenergic receptors on the smooth muscle cells (Dora et al. 2000).

The present results may have implications for understanding how the increased release of endotheliumderived NO and EDHF might affect tissue perfusion in the thyroid gland. Thyroid vascular expansion and endothelial cell proliferation in goitrous rats are significantly inhibited after treatment with the NO synthase inhibitor L-NMMA (Colin et al. 1997), thus suggesting a role for $\mathrm{NO}$ in the abnormal vascular changes in thyroid hyperplasia. It remains to be determined whether EDHF, due to its powerful relaxation effects, may represent a novel mechanism for regulating vascularity and maintaining a high tissue perfusion in the thyroid gland.

In conclusion, we have demonstrated that in human thyroid arteries the endothelium significantly modulates responses to acetylcholine and noradrenaline through the release of $\mathrm{NO}$ and EDHF. EDHF-mediated relaxation involves activation of charybdotoxin- and apaminsensitive $\mathrm{K}^{+}$channels.

\section{Funding}

Supported by Ministerio de Ciencia y Tecnología (BFI 2003-01412) and Fondo de Investigaciones Sanitarias (02/3045).

\section{References}

Angus JA, Cocks TM \& Satoh K 1986 The alpha adrenoceptors on endothelial cells. FASEB Journal 45 2355-2359.

Campbell WB, Gebremedhin D, Pratt PF \& Harder DR 1996 Identification of epoxyeicosatrienoic acids as endothelium-derived hyperpolarizing factors. Circulation Research 78 415-423.

Chauhan SD, Nilsson H, Ahluwalia A \& Hobbs AJ 2003 Release of C-type natriuretic peptide accounts for the biological activity of endothelium-derived hyperpolarizing factor. PNAS 100 1426-1431.

Coats P, Johnston F, MacDonald J, McMurray JJV \& Hillier C 2001 Endothelium-derived hyperpolarizing factor. Identification and mechanisms of action in human subcutaneous resistance arteries. Circulation 103 1702-1708.

Cohen RA \& Vanhoutte PM 1995 Endothelium-dependent hyperpolarization: beyond nitric oxide and cyclic GMP. Circulation 92 3337-3349.

Colin IM, Kopp P, Zbaren J, Haberli A, Grizzle WE \& Jameson JL 1997 Expression of nitric oxide synthase III in human thyroid follicular cells: evidence for increased expression in hyperthyroidism. European Journal of Endocrinology 136 649-655.

Dora KA, Doyle MP \& Duling BR 1997 Elevation of intracellular calcium in smooth muscle causes endothelial cell generation of NO in arterioles. PNAS 94 6529-6534.

Dora KA, Hinton JM, Walker SD \& Garland CJ 2000 An indirect influence of phenylephrine on the release of endothelium-derived vasodilators in rat small mesenteric artery. British Journal of Pharmacology 129 381-387. 
Doughty JM, Plane F \& Langton PD 1999 Charybdotoxin and apamin block EDHF in rat mesenteric artery if selectively applied to the endothelium. American Journal of Physiology 276 H1107-H1112.

Edwards G, Dora KA, Gardener MJ, Garland CJ \& Weston AH 1998 $\mathrm{K}^{+}$is an endothelium-derived hyperpolarizing factor in rat arteries. Nature 396 269-272.

Feletou M \& Vanhoutte PM 1988 Endothelium-dependent hyperpolarization of canine coronary smooth muscle. British Journal of Pharmacology 93 515-524.

Fisslthaler B, Popp R, Kiss L, Potente M, Harder DR, Fleming I \& Busse R 1999 Cytochrome P450 2C is an EDHF synthase in coronary arteries. Nature 401 493-497.

Hermenegildo C, Medina P, Peiró M, Segarra G, Vila JM, Ortega J \& Lluch S 2002 Plasma concentrations of asymmetric dimethylarginine, an endogenous inhibitor of nitric oxide synthase, is elevated in hyperthyroid patients. Journal of Clinical Endocrinology and Metabolism 87 5636-5640.

Jones CJ, DeFily DV, Patterson JL \& Chilian WM 1993 Endothelium-dependent relaxation competes with alpha 1- and alpha 2-adrenergic constriction in the canine epicardial coronary microcirculation. Circulation 87 1264-1274.

Katz SD \& Krum H 2001 Acetylcholine-mediated vasodilation in the forearm circulation of patients with heart failure: indirect evidence for the role of endothelium-derived hyperpolarizing factor. American Journal of Cardiology 87 1089-1092.

Lüscher TF \& Vanhoutte PM 1990 The Endothelium: Modulator of Cardiovascular Function. Boca Raton: CRC Press.

Martínez MC, Vila JM, Aldasoro M, Medina P, Chuan P \& Lluch S 1994 The human deferential artery: endothelium-mediated contraction in response to adrenergic stimulation. European Journal of Pharmacology 261 73-78.

Matoba T, Shimokawa H, Nakashima M, Hirakawa Y, Mukai Y, Hirano K, Kanaide H \& Takeshita A 2000 Hydrogen peroxide is an endothelium-derived hyperpolarizing factor in mice. Journal of Clinical Investigation 106 1521-1530.

Matoba T, Shimokawa H, Kutota H, Morikawa K, Fujiki T, Kunihiro I, Mukai Y, Hirakawa Y \& Takeshita A 2002 Hydrogen peroxide is an endothelium-derived hyperpolarizing factor in human mesenteric arteries. Biochemical and Biophysical Research Communications 290 909-913.

Medina P, Noguera I, Aldasoro M, Vila JM, Flor B \& Lluch S 1997 Enhancement by vasopressin of adrenergic responses in human mesenteric arteries. American Journal of Physiology 272 H1087-H1093.

Millatt LJ, Johnstone AP, Nussey SS \& Whitley GS 2000 Thyrocyte release of asymmetric dimethylarginine does not account for human thyrocyte inhibition of endothelial cell cyclic GMP. European Journal of Endocrinology 142 493-499.

Miura H, Liu Y \& Gutterman DD 1999 Human coronary arteriolar dilation to bradykinin depends on membrane hyperpolarization: contribution of nitric oxide and $\mathrm{Ca}^{2+}$-activated $\mathrm{K}^{+}$channels. Circulation 99 3132-3138.

Palmer RMJ, Ashton DS \& Moncada S 1988 Vascular endothelial cells synthesize nitric oxide from L-arginine. Nature 333 664-666.

Petersson J, Zygmunt PM \& Hogestatt ED 1997 Characterization of the potassium channels involved in EDHF-mediated relaxations in cerebral arteries. British Journal of Pharmacology 120 1344-1350.

Randall MD, Alexander SP, Bennett T, Boyd EA, Fry JR, Gardiner SM, Kemp PA, McCulloch AI \& Kendall DA 1996 An endogenous cannabinoid as an endothelium-derived vasorelaxant. Biochemical and Biophysical Research Communications 229 114-120.

Rees DD, Palmer RMJ, Hodson HF \& Moncada S 1989 A specific inhibitor of nitric oxide formation from L-arginine attenuates endothelium-dependent relaxation. British Journal of Pharmacology 96 418-424.

Rees DD, Palmer RMJ, Schulz R, Hodson HF \& Moncada S 1990 Characterization of three inhibitors of endothelial nitric oxide synthase in vitro and in vivo. British Journal of Pharmacology 101 746-752.

Scotland RS, Chauhan S, Vallance PJ \& Ahluwalia A 2001 An endothelium-derived hyperpolarizing factor-like factor moderates myogenic constriction of mesenteric resistance arteries in the absence of endothelial nitric oxide synthase-derived nitric oxide. Hypertension 38 833-839.

Segarra G, Medina P, Acuña A, Domenech C, Martínez-León JB, Vila JM \& Lluch S 1999 Comparative effects of dilator drugs on human penile dorsal artery and deep dorsal vein. Clinical Science $\mathbf{9 6}$ $59-65$.

Segarra, G, Medina, P, Vila, JM, Martínez-León, JB, Ballester, RM, Lluch, P \& Lluch, S 2000 Contractile effects of arginine analogues on human internal thoracic and radial arteries. Journal of Thoracic and Cardiovascular Surgery 120 729-736.

Segarra G, Medina P, Vila JM, Chuan P, Domenech C \& Lluch S 2002 Increased contraction to noradrenaline by vasopressin in human renal arteries. Journal of Hypertension 20 1373-1379.

Shimokawa H \& Takeshita A 1995 Endothelium-dependent regulation of the cardiovascular system. Internal Medicine 34 939-946.

Suzuki H \& Cheng G 1990 Endothelium-derived hyperpolarizing factor (EDHF): an endogenous potassium-channel activator. News in Physiological Sciences 5 212-215.

Taylor SG \& Weston AH 1988 Endothelium-derived hyperpolarising factor: a new endogenous inhibitor from the vascular endothelium. Trends in Pharmacological Sciences 9 272-274.

Urakami-Harasawa L, Shimokawa H, Nakashima M, Egashira K \& Takeshita A 1997 Importance of endothelium-derived hyperpolarizing factor in human arteries. Journal of Clinical Investigation 100 2793-2799.

Vallance P, Collier J \& Moncada S 1989 Effects of endotheliumderived nitric oxide on peripheral arteriolar tone in man. Lancet 2 997-1000.

Vanhoutte PM 1996 Endothelium-Derived Hyperpolarizing Factor. Amsterdam: Harwood Academic Publishers.

Yada T, Shimokawa H, Hiramatsu O, Kajita T, Shigeto F, Goto M, Ogasawara Y \& Kajiya F 2003 Hydrogen peroxide, an endogenous endothelium-derived hyperpolarizing factor, plays an important role in coronary autoregulation in vivo. Circulation 107 1040-1045.

Zygmunt PM 1996 Role of potassium channels in endotheliumdependent relaxation resistant to nitroarginine in the rat hepatic artery. British Journal of Pharmacology 117 1600-1606.

Zygmunt PM, Edwards AH, Weston AH, Larsson B \& Högestätt ED 1997 Involvement of voltage-dependent potassium channels in the EDHF-mediated relaxation of rat hepatic artery. British Journal of Clinical Pharmacology 121 141-149.

Received 28 January 2004

Accepted 2 March 2004

Made available online as an

Accepted Preprint 12 March 2004 